\title{
IMPLEMENTASI NILAI KEJUJURAN AKADEMIK PESERTA DIDIK DI LINGKUNGAN SEKOLAH DASAR
}

\author{
Ahmad Hariandi \\ Pendidikan Guru Sekolah Dasar Universitas Jambi \\ Email : ahmad.hariandi@unja.ac.id \\ Vira Puspita \\ Pendidikan Guru Sekolah Dasar Universitas Jambi \\ Email : virapuspita099@gmail.com \\ Anis Apriliani \\ Pendidikan Guru Sekolah Dasar Univeritas Jambi \\ Email : aprilianianis@gmail.com \\ Putri Ernawati \\ Pendidikan Guru Sekolah Dasar Universitas Jambi \\ Email : putriernawati07@gmail.com \\ Suci Nuhasanah \\ Pendidikan Guru Sekolah Dasar Universitas Jambi \\ Email : sucinuhasanah04@gmail.com
}

\begin{abstract}
Character education is defined as the education of values, character, moral education character education, who aim the develop yeh ability of students to give good or bad decisions. And manfest goodness in everyday life with all heart and realize lofty ideals. One attitude that shows a person who has good character is honest attitude. Honest attitude needs to be instilled by parenst and educators to children as early as possible. Iven the importance of honesty in this modern area, researchers are interested in examing how the implementation of the value of academic honesty of students in Elementary School environment. This study aims to describe the implementation of acdeic honesty values of students in Elementary School environment when the exam situation and the underlying motives. This study uses a phenomenological qualitative research method with literature study methods and observations and interviews obtained from informants.
\end{abstract}

Keyword: Character Education, Academic Honesty, Students

\begin{abstract}
Abstrak
Pendidikan karakter dimaknai sebagai pendidikan nilai, budi pekerti, pendidikan moral, pendidikan watak, yang tujuannya untuk mengembangkan kemampuan peserta didik untuk memberikan keputusan baik, buruknya dan mewujudkan kebaikan dalam kehidupan sehari- hari dengan sepenuh hati dan mewujudkan cita- cita luhur. Salah
\end{abstract}

Nur El-Islam, Volume 7, Nomor 1, April 2020 
satu sikap yang menujukkan pribadi yang memiliki karakter yang baik ialah sikap jujur. Sikap jujur perlu ditanamkan oleh orangtua dan pendidik kepada anak sedini mungkin. Mengingat pentingnya sikap jujur di era modern ini, peneliti tertarik untuk meneliti bagaimana implementasi nilai kejujuran akademik peserta didik di lingkungan Sekolah Dasar.Penelitian ini bertujuan untuk mendeskripsikan implementasi nilai kejujuran akademik peserta didik di lingkungan Sekolah Dasar saat situasi ujian serta motif yang mendasarinya. Penelitian ini menggunakan metode penelitian kualitatif fenomenologis dengan metode studi pustaka dan observasi serta wawancara yang didapat dari informan.

Kata kunci: Pendidikan karakter, kejujuran akademik, peserta didik

\section{A. Pendahuluan}

Menurut Undang- Undang Nomor 20 Tahun 2003 tentang Sistem Pendidikan Nasional pasal 3 menyatakan bahwa Pendidikan Nasional berfungsi untuk mengembangkan kemampuan dan membentuk watak serta peradaban bangsa yang bermartabat dalam rangka mencerdasakankehidupan bangsa, yang bertujuan untuk mengembangkan potensi peserta didik agar menjadi manusia yang beriman dan bertakwa serta berkahklak mulia, sehat, berilumu,cakap,kreatif, dan menjadi warga negara yang demokratis dan bertanggungjawab. ${ }^{1}$

Berdasarkan fungsi dan tujuan yang telah disebutkan maka harus ditekankan Pendidikan Nasional tersebut sebagai bentuk dari usaha dalam menanamkan karakter yang baik kepada peserta didik. Oleh karena itu, pada saat ini pemerintah mewajibkan kepada pendidik untuk menanamkan pendidikan kepada peserta didik. Pendidikan karakter jika ditinjau dari segi akademik dimaksudkan sebagai bentuk dari pendidikan nilai, pendidikan moral pendidikan akhlak, dan pendidikan budi pekerti yang bermaksud bagi peserta didik untuk memngembangkan dan untuk memberikan keputusan yang baik dan buruk sehingga dapat mewujudkan dan mengimplementasikan bentuk kebaikan dalam kehidupan sehari- hari.

Pendidikan karakter tidak lepas dari nilai- nilai dasar yang dilihat baik dan perlu ditanamkan sejak dini. Salah satunya adalah

${ }^{1}$ Undang-undang Republik Indonesia Nomor 20 Tahun 2003, Undang-undang Sisdiknas Tentang Sistem Pendidikan Nasional, (Jakrta: Sinar Grafika, 2008). 
nilai karakter jujur. Kejujuran di lingkungan Sekolah Dasar menjadi sangat penting untuk menjadikan karakter peserta didik saat ini sebagai bekal mengarungi era global dan kehidupan yang akan datang. Karakter kejujuran dalam konteks akademik dapat dilihat secara langsung di lingkungan sekolah. Dalam proses pembelajaran, guru harus mampu mengintegrasikan nilai- nilai kejujuran pada peserta didik. Guru mempunyai dua peran penting, yaitu mengajar dan mendidik. Kedua tugas tersebut harus dijalankan guru secara bersamaan.

Mengajar yaitu kegiatan membantu dan memberikan pelatihan kepada peserta didik dalam memahami pelajaran, sedangkan mendidik yaitu memberikan dorongan dan memberi arahan untuk peserta didik agar dapat maju menuju proses kedewasaan, yang meliputi kedewasaan intelektual, emosional, fisik, sosial, piritual, dan moral. Kurikulum yang diterapkan di Sekolah Dasar saat ini menggunakan Kurikulum 2013, yang didalamnya menggunakan penilaian autentik yang menilai peserta didik dengan menggunakan tiga ranah yaitu afektif, kognitif, dan psikomotor. Dengan adanya penilaian pada ranah afektif, pendidik dituntut untuk mampu menamkan karakter yang baik kepada peserta didiknya, salah satunya ialah nilai kejujuran. Sehingga proses kegiatan dalam pendidikan dapat memberikan hal-hal yang positif.

Berdasarkan latar belakang yang telah ditulis, peneliti memberikan identifikasi masalah yang akan dijadikan bahan penelitian yaitu pentingnya pendidikan karakter di lingkungan Sekolah Dasar dan mendeskripsikan Implementasi nilai kejujuran akademik peserta didik di lingkungan sekolah dasar.

Penelitian ini sejalan dengan penelitian yang dilakukan oleh Nila Hulaini mahasiswa Program Studi Pendidikan Agama Islam Universitas Islam Raden Fatah yang berjudul "Implementasi Pendidikan Karakter Jujur dalam Membentuk Kepribadian Siswa Kelas VII di SMPN 19 Palembang”. Hasil penelitiannya menunjukkan tingginya implementasi tingkat kejujuran peserta didik kelas VII SMP Negeri 19 Palembang. Penelitian ini bertujuan untuk mengetahui pengimplementasian dari nilai kejujuran akademik dilingkungan 
sekolah dasar yaitu salah stu sekolah dasar di Kabupaten Batanghari dan sebagai tugas akhir mata kuliah Pengembangan Moral dan Agama di sekolah dasar.

Penelitian ini menggunakan metode penelitian kualitatif fenomenologi dengan metode studi pustaka dan observasi serta wawancara yang didapat dari narasumber. Penelitian kualitatif yang bermaksud untuk memahami fenomena tentang apa yang dialami oleh subjek penelitian dengan cara deskripsi dalam bentuk kata-kata dan bahasa, pada suatu konteks yang alamiah dan menggunakan berbagai metode ilmiah. kajian ini diupayakan mendasar, mendalam, berorientasi dalam proses dan didasarkan pada pendapat adanya realita dinamika. ${ }^{2}$ Studi pustaka adalah metode pengumpulan data dengan mencarai informasi lewat buku, makalah koran dan literatur lainnya yang bertujuan untuk membentuk sebuah landasan teori. ${ }^{3}$

\section{B. Kajian Teoritik}

\section{Pengertian Pendidikan Karakter}

Pendidikan adalah sebuah peroses perubahan sikap dan tingkah laku individu atau sekelompok orang dalam usaha mendewasakan seseorang melalui pengajaran dan pelatihan. Menurut Jalaludin pendidikan adalah sebuah bentuk proses, bukan aktivitas spontan yang langsung jadi. ${ }^{4}$ Ada berbagai macam bentuk komponen yang akan dijadikan penopang dari setiap beberapa aktivitas pendidikan, komponen yang antar sesamanya saling tergantung, saling berhubungan, dan saling menentukan. Pendidikan adalah sebuah bentuk upaya penghubung dua sisi, sisi pertama yaitu individu yang sedang tumbuh dan disisi yang kedua yaitu berupa nilai sosial, moral dan intelektual yang menjadi tanggung jawab seorang pendidik untuk mendorong individu atau peserta didik tersebut. Pendidikan bertujuan untuk membangun karakter anak didik yang kuat menghadapi macam

\footnotetext{
${ }^{2}$ Moleong, Lexy J Metode Penelitian Kualitatif (Bandung : PT. Remaja Rosdakarya,2013)

${ }^{3}$ Arikunto, Suharsimi.Prosedur Penelitian : Suatu Pendekatan Praktik. (Jakarta : PT. Rineka Cipta,2016)

${ }^{4}$ Jalaludin, Psikologi Agama (Jakarta: PT .RajaGrafindo Persada, 2015), h.174-175
} 
cobaan dalam kehidupanya. Pendidikan tidak terlepas dari sumbur pokok ajara yaitu al-quran. Al-quran sebagai tuntunan dan pedoman bagi umat. Jadi pendidikan adalah proses mengubah tingkah laku anak didik agar jadi manusia dewasa yang mampu hidup mandiri dan sebagai anggota masyarakat dalam lingkungannya. Secara Etimologis karakter berarti tabiat, sifat-sifat kejiwaan, ahlak atau budi pekerti yang membedakan anatara manusia yang satu dengan manusia yang lainnya. Orang yang berkarakter berarti orang yang memiliki watak, kepribadian, budi pekerti dan ahlak.

Karakter merupakan kumpulan dari beberapa nilai-nilai yang menuju pada suatu sistem dengan melandasi pemikiran, perasaan, sikap dan perilaku yang ditampilkan oleh seseorang. ${ }^{5}$

Karakter dapat diartikan sebagai watak, tabiat, ahlak atau kejiwaan seseorang. Dari beberapa pendapat para ahli dapat disimpulkan karakter adalah kepribadian seseorang yang terbentuk dari proses internalisasi yang digunakan sebagai landasan untuk cara pandang, perpikir, bersikap dan bertindak. ${ }^{6}$

Hamdani, pendidikan karakter adalah rangkaian prinsip dasar moral dan keutamaan sikap serta watak yang dimiliki dan dijadikan kebiasaan oleh anak sejak masa kecil sampai dewasa. ${ }^{7}$ Ammirullah Syarbini, pendidikan karakter yaitu sebuah upaya untuk membentuk kepribadian seseorang melalui proses mengetahui kebaikan, mencintai kebaikan dan melakukan kebaikan. ${ }^{8}$ Jadi pendidikan karakter merupakan sebuah upaya yang terencana untuk menjadikan peserta didik mengenal, peduli dan menginternalisasikan nilai-nilai sehingga peserta didik menjadi insan yang berguna. Tujuan dari pendidikan karakter yaitu untuk memebentuk mental dan sikap siswa

${ }^{5}$ Amirulloh Syarbini, Pendidikan Karakter Berbasis Keluarga, (Jakarta : Ar-ruzz Media,2016) h,11

${ }^{6}$ Muhammad Najid, dkk, Manajemen Strategi Pendidikan karakter Bagi Anak Usia Dini (Yogyakarta: Gava Media, 2016) h.58

${ }^{7}$ Hamdani Hamid dan Beni Ahmad Saebani, Pendidikan Karakter Prespektif Islam (Bandung: Pustaka Setia, 2013), h, 31

${ }^{8}$ Amirullah Syarbini, Pendidikan Karakter Berbasis Keluarga (Jakarta: Ar-Ruzz Media, 2016), h. 42 
yang dikelola dengan menanamkan sikap-sikap religius dan nilai tradisional yang posotif.

Pendidikan karakter dalam dunia sekolah memiliki tujuan sebagai berikut:

1.) Menguatkan dan mengembangkan nilai- nilai yang ada dalam kehidupan yang dianggap sangat penting dan perlu dikembangkan sehingga menjadi kepribadian peserta didik yang khas.

2.) Mengoreksi perilaku peserta didik yang tidak sesuai dengan nilainilai yang dikembangkan oleh sekolah .

3.) Membangun koneksi yang harmoni antara keluarga dan masyarakat untuk memerankan tanggung jawab pendidikan karakter secara bersama-sama.

Dalam membentuk karakter seorang anak untuk menjadi pribadi yang jujur memerlukan proses dan waktu secara bertahap. Karakter jujur yaitu salah satu karakter yang paling penting dan perlu dikembangkan untuk membentuk karakter anak selanjutnya. Dalam konteks pembangunan karakter pembangunan di sekolah, kejujuran adalah kunci utama yang harus dikembangan untuk peserta didik. Karakter dapat dilihat secara langsung dalam kehidupan dikelas ataupun disekolah.

\section{Pengertian Kejujuran}

Lestari dan Adianti menyebutkan bahwa jujur merupakan bentuk dari penyampaian secara dengan benar dan berupaya untuk mendapatkan sesuatu dengan cara yang benar, bentuk dari kejujuran akademik adalah berbicara apa adanya, terbuka, konsisten dengan apa yang dikatakan dan juga apa yang dilakukan, berani karena benar, serta dapat dipercaya, teori terseut dijelaskan oleh Jamani, Arkanudin, dan Syamiati .9 Selain itu Zubaidi menyebutkan bahwa kejujuran merupakan kemampuan dalam menyampaikan kebenaran yaitu dapat mengakui kesalahan, dapat dipercaya dan bertindak secara hormat. ${ }^{10}$

${ }^{9}$ Lestari,S. \&adiyanti,MG.Konsep Jujur Dalam Prespektif Orang.(2012)

${ }^{10}$ Zubaedi, Desain Pendidikan Karakter, Konsepsi dan Aplikasi dalam Lembaga Pendidikan.(Jakarta: PT. Kencana ,2011) 
Sedangkan Muhammad Mustari menjelaskan pengertian jujur yaitu suatu perilaku manusia yang didasarkan atau dilandasi pada usaha sehingga menjadikan dirinya sebagai orang yang dapat dipercaya dalam perkataan, tindakan, dan pekerjaan baik terhadap dirinya ataupun orang lain. ${ }^{11}$

Ahli yang lain juga menyebutkan bahwa jujur adalah suatu nilai dan prinsip yang harus ditanamakan pada diri seseorang dari pendidikan dasar atau sejak dini. Dari berbagai pendapat ahli tersebut, dapat disimpulkan bahwa jujur merupakan salah satu karakter atau sikap yang harus ditanamkan pada peserta didik khussunya pada awal kelas rendah agar mereka dapat tumbuh menjadi pribadi yang dapat dipercaya baik dalam perkataan, tindakan, dan pekerjaan terhadap diri sendiri maupun orang lain baik dirumah di sekolah maupun di lingkungan masyarakat. Kejujuran dalam menyampaikan sebuah pesan merupakan prinsip dasar dalam berkomunikasi, jika prinsip tersebut tidak dapat tegak dengan baik maka akan berakibat fatal bagi manusia. Diantara bentuk kejujuran dalam berkomunikasi yaitu :

1. Tidak berbohong

Berbohong merupakan kegiatan memanipulasi informasi sehingga informasi tersebut tidak sampai sebagaimana mestinya, sehingga kegiatan berbohong tersebut akan menimbulkan presepsi yang tidak benar.

2. Tidak memutar balikan fakta

Memutar balikan fakta merupakan fitnah yang dapat membuat keruh suasana dan dapat menimbulkan ketidak harmonisaan hubungan sehingga hal tersebut dapat menimbulkan orang baik akan menjadi pengkhianat dan orang pengkhianat menjadi orang yang baik.

${ }^{11}$ Mohammad Mustari,Nilai Karakter Refleksi Untuk Pendidikan,(Jakarta : PT Raja Grafindo Persads,2014) 


\section{Macam- macam Kejujuran}

jujur terbagi menjadi atas jujur dalam niat, 'jujur dalam ucapan, jujur dalam tekad dan menikmati janji, sedangkan jujur dalam perbuatan dan jujur dalam kedudukan agama sebagi berikut: ${ }^{12}$

a.) Jujur dalam niat dan kemauan seseorang

Dalam islam setiap aktivitas senantiasa didasakan pada niat orang yang melakukan kegiatan tersebut. Niat merupakan inti dari segala aktivitas sedangkan kejujuran adalah kuncinya. Jika suatu amal tercampuri dengan kepentingan dunia, maka akan merusakkan kejujuran, niat, dan orang tersebut bisa dikatakan sebagai pendusta.

b.) Jujur dalam ucapan

jujur dalam ucapan adalah alat yang dapat menjaga manusia dari kebinasaan dan wajib bagi seorang hamba menjaga lisanya, yaitu tidak berkata kecuali dengan benar dan jujur. Hal tersebut merupakan jenis kejujuran yang paling tampak dan jelas diantara macam-macam kejujuran.

c.)Jujur dalam tekad dan menepati janji

Bentuk dari jujur dalam bertekad bisa dilihat dari ucapan sesorang dalam mengambil keputusan atau pun melakukan sesutu dengan dengan sungguh-sungguh. Sedangkan dalam menepati janji adalah ketika sesorang sudah berucap dan membuat kesepakatan dan orang tersebbut menepatinya sesuai dengan ucapanya berarti hal tersebut bisa dikatakan menepati ucapan dan janjinya.

d.)Jujur dalam perbuatan

Jujur dalam perbuatan merupakan seimbang antara lahiriyah dan batin, hingga tidaklah berbeda antara amal lahir dengan amal batin.

e.) Jujur dalam kedudukan agama

Hal ini merupakan kedudukan yang paling tinggi, sebagaimana jujur dalam rasa takut dan harapan, dalam rasa cinta dan tawakal. Hal tersebut memiliki tekad yang kuat dan akan tampak jika dipahami hakikat dan tujuannya. Jika seseorang menjadi sempurna

\footnotetext{
${ }^{12}$ A.tabrani Rusyan, Pendidikan Budi Pekerti,( Jakarta: PT. Inti Media Cipta Nusantara, 2006)h.21-24
} 
dengankejujuranya maka akan dikatakan orang ini adalah benar dan jujur.

\section{Cara Memulai Bersikap Jujur}

Ada beberapa cara dalam memulai sikap jujur yaitu dengan cara tidka melakukan sessuatu yang tidak etis sehingga akan memaksa kita untuk berdusta atau berbohong dan melakukan sesuatu yang memalukan di kemudian hari. Sifat jujur ialah salah satu ciri dari keislaman, dasar agama, timbangan keimanan, dan tanda kesempurnaan bagi si pemilik sikap tersebut. Dengan kejujuran, manusia akan dapat mencapai derajat orang yang mulia dan selamat dari hal- hal buruk.

1.) Keutamaan kejujuran

Nabi Muhammad SAW menganjurkan ummatnya untuk bersikap jujur karena jujur merupakan akhlak mulia yang akan mnegarahkan kepada akhlak tersebut . ada 4 keutamaan jujur, diantaranya sebagai berikut:

a.) Menentramkan hati

Nabi Muhammad SAW bersadba bahwa jujur merupakan ketentraman dari hati

b.) Membawa berkah

Nabi Muhammad SAW bersabda bahwa dua orang yang sedang melakukan transaksi jual beli boleh saling pilih- memilih selama belum berpisah. Jika keduanya jujur maka akan terus diberkahi dalam transaksi jual beli. Dan jika keduanya melakukan kebohongan

c.) Meraih kedudukan yang syahid

Rasulullah SAW bersabda barangsiapa yan meminta syahid kepada Allah dengan secra asungguh- sungguh, maka Allah akan menaikkan derajat orang itu ketempat para syuhada meskipunn ia mati d temapt tidurnya.

d.) Mendapat keselamatan

Berbuat dusta dalam hal-hal tertentu diperbolehkan, jika perilaku jujur dapat menimbulkan kekacauan. 
C. Hasil Penelitian dan Pembahasan

1. Hasil Temuan Bentuk Perilaku Jujur Dan Tidak Jujur

Bentuk perilaku jujur dan tidak jujur ketika mengerjakan ujian dapat dilihat dalam tiga situasi, yaitu:

a.) Ketika peserta didik mengerjakan ujian dua mata pelajaran secara bersamaan sedangkan hanya satu mata pelajaran yang sempat dipelajari.

b.) Ketika pesserta didik sedang melaksanakan ujian dan mengalami kesulitan dalam mengerjakan soal, kemudian melihat temantemannya saling mencontek

c.) Ketika peserta didik belum tuntas dalam belajar namun telah membuat catatan kecil dan peserta didik mengalami kesulitan dalam menjawab soal.

Berikut merupakan hasil observasi perbandingan dari bentuk perilaku jujur dan tidak jujur ketika peserta didik sedang melaksanakan ujian dapat dilihat pada tabel berikut:

Tabel 1.1 Perbandingan perilaku jujur dan tidak jujur pada situasi mengerjakan ujian.

\begin{tabular}{|c|l|c|c|}
\hline No & \multicolumn{1}{|c|}{ Situasi } & Jujur & Tidak Jujur \\
\hline 1. & $\begin{array}{l}\text { Peserta didik menghadapi ujian } \\
\text { dua mata pelajaran, sedangkan } \\
\text { hanya satu mata pelajaran yang } \\
\text { hanya sempat dipelajari. }\end{array}$ & $\mathbf{1 1 , 3 \%}$ \\
\hline 2. & $\begin{array}{l}\text { Peserta didik kesulitan } \\
\text { mengerjakan soal ujian dan } \\
\text { melihat teman- temannya saling } \\
\text { mencontek saat penagwas keluar } \\
\text { ruangan ujian. }\end{array}$ & $\mathbf{2 7 , 9 \%}$ \\
\hline 3. & $\begin{array}{l}\text { Peserta didik belum tuntas dalam } \\
\text { belajar namun telah membuat } \\
\text { catatan kecil dan peserta didik } \\
\text { mengalami kesuliatan dalam } \\
\text { menjawab soal. }\end{array}$ & $\mathbf{5 4 , 4 \%}$ \\
\hline
\end{tabular}


Dari tabel di atas dapat disimpulkan bahwa pada saat mengerjakan ujian, tingkat kejujuran peserta didik tergolong tinggi. Hal tersebut dapat dilihat pada situasi ketika pesserta didik menghadapi ujian dua mata pelajaran sekaligus sedangkan hanya satu mata pelajaran yang sempat dipelajari. Pada situasi ini, pesserta diidk berusaha meluangkan diri untuk mempelajari materi kedua karena peserta diidk mempunyai waktu dan kessempatan untuk belajar sebelum ujian kedua berlangsung.

Bentuk perilaku tidak jujur yang ditunjukkan peserta didik dalam ujian yaitu berbuat sedikit curang dengan cara melihat jawaban teman, bertanya kepada teman, dan mengharapkan bantuan teman. Meniru pekerjaan teman, bertanya langsung kepada teman saat mengerjakkan ujian dan saling tukar hasil pekerjaan dengan teman merupakan tindakan yang dpat dikategorikan sebagai perbuatan mencontek.

Pada situasi peserta didik belum tuntas dalam belajar dan mengalami kesulitan dalam menjawab soal namun peserta didik telah membuat antisipasi dengan membuat catatan keci, perilaku jujur lebih banyak muncul karena saat ujian berlangsung pengawasan dal ruang ujian sangat ketat sehingga peserta didik tidak berani mengambil resiko apabila memanfaatkan kertas contekkan yang telah dibuat, oleh karena itu hal tersebut dapat menekankan tingkat kecurang yang terjadi.

Pada situasi seperti ini bentuk perilaku jujur yang terungkap yaitu menunjukkan perilaku jujur dengan bentuk perilaku yaituberusaha mengingat-ingat kembali materi pelajaran yang telah dipelajari sebelumnya perilaku tersebut bertujuan untuk menjaga kepercayaan yang telah diberikan oleh orang tua. Perilaku anak menyesuaikan bagaimana perilaku yang diajarkan orang tuanya, sehingga orang tua menjadi panutan anak-anaknya. Penanaman nilainilai kejujuran menuntut kehidupan sosial yang mendukung untuk meralisasikan nilai-nilai tersebut.Keteladanan yang tunjukkan oleh orang tua dan guru akan menjadikan peserta didik mendapatkan model yang tepat untuk dijadikan cermin telatan kepribadian dlam kehidupan mereka. Tanpa menyertkan keteladanan (kejujuran) pada 
pribadi orang tua dan guru, bisa jadi peserta didik nantinya akan kehilangan figur publik yang bisa mnegantarkan mereka menjadi manusia yang seutuhnya baik dan religius.

Bentuk perilaku yang tidak jujur yang muncul pada saat melaksanakan ujian yaitu berbuat curang dan memanfaatkan kesempatan yang ada dengan cara membuka catatan kecil yang telah disiapkan sebelumnya, bertanya kepada teman, mencontek teman, mencari kesempatan yang tepat, hingga beralasan kekamar mandi untuk membuka contekan. Meminjam dan menyalin penuh tugas dari orang lain maupun menyalin jawaban pada saat ujian termasuk dalam tindakan ketidak jujuran akademik. Perilaku mencontek dapat dilakukan dengan dua cara, yaitu dengan membuka contekan (pada kertas kecil yang telah disipakan atau membuka buku) dan bertanya pada teman pada saat ujian.

Namun pada situasi saat peserta didik kesulitan dlam mengerjakan soal kemudian melihat teman-temanya mencontek saat pengawas sedang keluar ruangan, peserta didik mulai menunjukkan beberapa perilaku tidak jujur. Hali ini terjadi karena adanya pengaruh dari lingkungan yaitu teman-teman yang slaing mnecontek dan pengawasan yang longgar sehingga situasi tersebut dimanfaatkan siswa sebagai kesempatan untuk berbuat tidak jujur.

Tujuan yang ingin dicapai peserta diddik dalam berperilaku jujur saat mengerjakan uijan yaitu agar tetap menjaga kejujuran, agar terhindar dari perilaku curang, ingin mengetahui sejauh mana kemampuan dirinya. Menjaga kejujuran dipertahankan peserta didik karena jujur merupakan ahlak yang baik serta terhindar dari perbuatan dosa. Didalam agama pun dianjurkan agar terhindar dari perbuatan dosa dalam agama pun dianjurkan agar manusia agar selalu berprilaku jujur. Moral adalah ajaran tentnag baik buruknya suatu perbuatan dan kelakuan, ahlak, kewajiban, dan lain sebagainya. Moral erat kaitanya dengan kemampuan seseorang untuk membedakan antara perbuatan yang benar dan yang salah. Selain itu moral juga merupakan kontrol dalam bersikap dan bertingkah laku sesuai dengan nilai-nilai hidup. Kejujuran merupakan salah satu unsur kekuatan spiritual, ahlak mulia dan kepribadian dalam diri seseorang. 
Untuk perilaku tidak jujur yang ditunjukkan peserta didik yaitu memanfaatkan kesempatan yang ada saat pengawas ujian keluar ruangan, situasi ini diwujudkan dengan perilaku tidak menyia-nyaikan kesempatan yang ada dan memanfaatkan situasi tersebut dengan sebaik mungkin selain itu juga karena pengaruh melihat teman-teman lain yang sedang mencontek, sehingga siswa lain pun mengikuti untuk memanfaatkan situasi tersebut untuk saling mencontek. Faktor lingkungan dapat memepengaruhi seseorang untuk berperilaku mencontek. Apabila mayoritas teman-teman dari peserta didik mencontek maka peserta didik lainya pun akan mengikutinya serta pengaruh dari pengawasan yang longgar ketika ujian yang mendorong peserta didik untuk mencontek. Bentuk ketidak jujuran akademik peserta didik yaitu saling meniru dengan teman saat ujian memberi kertas jawaban ujian, dan mencuri tes ataupun soalujian. ${ }^{13}$

\section{Simpulan}

Bentuk perilaku jujur pada situasi mengerjakn ujian yaitu belajar sebelum dilaksanakannya ujian atau saat jeda pergantian ujian, berusaha mengerjakan sendiri semampunya, bertawakal, membiarkan teman yang melakukan perbuatan curang, menegakkan kejujuran, tidak menyontek, menasehati teman yang berbuat curang, berusaha menginta- ingat materi, mengabaikan situasi yang terjadi didalam ruangan, serta tetap mengedepankan sisi keagamaan. Bentuk perilaku tidak jujur yaitu meminta jawaban kepada teman, melihat jawaban teman, bertanya kepada teman, mengharapkan bantuan teman, ikut mencontek, memanfaatkan situasi ujian yang longgar, membuka contekan yang telah disiapkan, mencari kesempatan, hingga beralasan kekamar mandi. Situasi mengerjakan ujian sedangkan saat pengawas keluar dari ruangan ujian, peserta didik mulai menunjukkan bentuk perilaku tidak jujur seperti bertanya kepada teman, ikut mencontek seperti yang dilakukan temna- teman, meminta jawaban,

${ }^{13}$ Schmelkin, I.. P., \& dkk. A Multidimensional Scaling of College Students” Perceptions of Academic Dishonesty. The Journal of Higher Education, (2008) h.587-607. 
memanfaatkan situasi, dan membuka kertas contekan yang telah disiapkan sebelumnya.

\section{Daftar Pustaka}

Amirullah Syarbini, Pendidikan Karakter Berbasis Keluarga, Jakarta: ArRuzz Media, 2016

Amirulloh Syarbini, Pendidikan Karakter Berbasis Keluarga, Jakarta : Arruzz Media,2016

Arikunto. Suharsimi. Prosedur Penelitian : Suatu Pendekatan Praktik. Jakarta : Rineka Cipta, 2016

A.tabrani Rusyan,Pendidikan Budi Pekerti, Jakarta: Inti Media Cipta Nusantara, 2006

Emosda. H, Penanaman Nilai-nilai Kejujuran dalam Menyiapkan Karakter Bangsa.2011

Fatimah. E. Psikologi Perkembangan Peserta Didik,Bandung: CV Pustaka Setia, 2006

Gardner, Howard, Multiple Intelligences: The Theory in Practice A Reader. New York: Basic Books, 1993

Hamdani Hamid dan Beni Ahmad Saebani, Pendidikan Karakter Prespektif Islam, Bandung: Pustaka Setia, 2013

Jalaludin, Psikologi Agama,Jakarta: PT RajaGrafindeo Persada, 2015

Koss, J. Academic Dishonesty Among Adolescents, American Psychological Association, 2011

Lestari,S. \&adiyanti, M.G. Konsep Jujur Dalam Prespektif Orang.2012

Lestari, S., \& Adiyanti, M. G. The Concept of Honesty in Javanese People's Perspective. Anima, Jurnal Psikologi Indonesia, 2012

Moleong, Lexy J. Metode Penelitian Kualitatif,Edisi Revisi. Bandung : PT. Remaja Rosdakarya, 2013 
Mohammad Mustari,Nilai Karakter Refleksi Untuk Pendidikan,Jakarta : PT Raja Grafindo Persada, 2014

Muhaimin, Pengembangan Kurikulum Pendidikan Agama Islam di

Sekolah, Madrasah,dan Perguruan Tinggi. Jakarta: Raja Grafindo Perkasa, 2005

Muhammad Najid, dkk, Manajemen Strategi Pendidikan karakter Bagi Anak Usia Dini, Yogyakarta: Gava Media, 2016

Nursalam, N., Bani, S., \& Munirah, M. Bentuk Kecurangan Akademik (Academic Cheating) Mahasiswa Pgmi Fakultas Tarbiyah dan Keguruan Uin Alaudin Makassar. Lentera Pendidikan: Jurnal Ilmu Tarbiyah dan Keguruan, 2013

Schmelkin, I. P., \& dkk. A Multidimensional Scaling of College Students Perceptions of Academic Dishonesty. The Journal of Higher Education,2008

Undang-undang Republik Indonesia Nomor 20 Tahun 2003,Undangundang Sisdiknas Tentang Sistem Pendidikan Nasional, Jakrta: Sinar Grafika, 2008

Zubaedi,Desain Pendidikan Karakter, Konsepsi dan Aplikasi dalam Lembaga Pendidikan, Jakarta: Kencana, 2011 